\title{
Etanercept discontinuation in a cohort of juvenile idiopathic arthritis patients: etanercept inefficacy but not intolerance is associated with oral corticosteroid use TR Southwood*, CL Cummins, C Cotter and J Rahman
}

Address: University of Birmingham, Birmingham, UK

* Corresponding author

from $15^{\text {th }}$ Paediatric Rheumatology European Society (PreS) Congress

London, UK. 14-17 September 2008

Published: 15 September 2008

Pediatric Rheumatology 2008, 6(Suppl I):P88 doi:I0.I I86/I546-0096-6-SI-P88

This abstract is available from: http://www.ped-rheum.com/content/6/SI/P88

(c) 2008 Southwood et al; licensee BioMed Central Ltd.

The British Society for Paediatric and Adolescent Rheumatology (BSPAR) Biologics Register monitors JIA patients treated with etanercept +/- methotrexate. We report duration of etanercept use and reasons for discontinuation, defined as cessation due to disease control or treatment failure; not including precautionary or temporary drug discontinuation for transient adverse events. KaplanMeier survival analysis was conducted with remaining patients censored at five years follow-up.

\section{Results}

From 2004-8, 434 etanercept treated JIA patients were enrolled; $68 \%$ female, $15.7 \%$ systemic arthritis, mean age at starting etanercept 11 years (2-21 years). At initiation of etanercept, $173(40 \%)$ were also being treated with oral corticosteroids (the "steroid+" group). In 846 patient years of follow up, 83/434 patients (19.1\%) discontinued etanercept for recorded reasons, 46 of whom (55\%) were in the steroid+group (table 1 ).

Discontinuations were due to treatment inefficacy rather than treatment intolerance in the steroid+ group $(\mathrm{p}=$ 0.01). Of the 5 discontinuations due to infection related adverse events, 4 were in the steroid+ group. Using 5 year Kaplan-Meier analysis, 55\% of all etanercept treated patients (95\% confidence intervals $44.4 \%$ - 65.6\%) had not experienced treatment failure. Discontinuation at 5 years was not associated with initial disease severity by physicians global assessment, systemic arthritis subtype, starting etanercept before age 10, disease onset before age 5 , concurrent methotrexate use or chronic anterior uveitis. 
Table I: Reasons for stopping Etanercept

\begin{tabular}{lllll}
\hline Pt Group & Inefficacy & Intolerance & Non-compliance & Disease control \\
\hline Steroidt & $30(65.2 \%)$ & $6(13 \%)$ & $6(13 \%)$ & $4(8.7 \%)$ \\
Steroid- & $14(37.8 \%)$ & $14(37.8 \%)$ & $4(10.8 \%)$ & $5(13.5 \%)$ \\
& 44 & 20 & 10 & 9
\end{tabular}

Publish with Bio Med Central and every scientist can read your work free of charge

"BioMed Central will be the most significant development for disseminating the results of biomedical research in our lifetime. " Sir Paul Nurse, Cancer Research UK

Your research papers will be:

- available free of charge to the entire biomedical community

- peer reviewed and published immediately upon acceptance

- cited in PubMed and archived on PubMed Central

- yours - you keep the copyright

Submit your manuscript here:

http://www.biomedcentral.com/info/publishing_adv.asp 